\title{
Trade, status and management of three parrots in the North Moluccas, Indonesia: White Cockatoo Cacatua alba, Chattering Lory Lorius garrulus and Violet-eared Lory Eos squamata
}

\author{
FRANK R. LAMBERT
}

\begin{abstract}
Summary
Between October 1991 and February 1992 field surveys on the status of parrots in the North Moluccas were conducted on Obi, Bacan and Halmahera, with principal focus on three significantly traded species, White Cockatoo Cacatua alba, Chattering Lory Lorius garrulus and Violet-necked Lory Eos squamata. Variable circular plots and variable-distance line transects were used to estimate minimum and maximum population densities at each of 18 sites. C. alba and L. garrulus preferred forest, the former largely confined to lowlands to $600 \mathrm{~m}$, the latter occurring more in hilly areas to at least $1,300 \mathrm{~m}$. E. squamata frequented all habitat types, being commoner in disturbed habitats though rarer at higher altitudes. Minimum populations (the first two being global) were 50,000, 46,000 and 66,000 respectively, and minimum estimated captures in $19915,120,9,600$ and 2,850, indicating overexploitation of the first two species. To ensure sustainability, total annual catch quotas should be reduced to $1,710,810$ and 1,590 respectively and allow for fair division between islands. Training, enforcement, monitoring, research and habitat conservation are all needed.
\end{abstract}

\section{Introduction}

Of the few parrot population surveys that have been conducted in eastern Indonesia, only one (Milton and Marhardi 1987) has investigated parrot populations in the North Moluccas, within Maluku Province. Other surveys (e.g. Noerdjito 1986, LIPI 1991) have concentrated on parrots in the province of Irian Jaya. This paper, which is a condensed version of Lambert (1993), documents the findings of field surveys of parrots, interviews with trappers and traders, and visits to bird markets (also throughout Indonesia), undertaken from October 1991 to February 1992 in the North Moluccan islands of Bacan, Obi and Halmahera. A brief summary of these findings is in Bräutigam and Humphreys (1992).

The primary objective of these surveys was to assess the biological status of the parrot species on the islands. Here I focus primarily on the three species for which data gathered during the project suggest that trapping levels might be significant: White Cockatoo Cacatua alba, Chattering Lory Lorius garrulus and Violet-necked Lory Eos squamata. The Eclectus Parrot Eclectus roratus, although protected from trapping and trade by Indonesian law, is caught in small numbers in the North Moluccas. 
C. alba and L. garrulus are endemic to the North Moluccas. On Obi and Bacan, L. garrulus is represented by the race flavopalliatus. L. garrulus is the most popular psittacine pet in the North Moluccas and is a very important species in both domestic and international trade. C. alba is less important on domestic markets, but is traded internationally in large numbers. E. squamata, represented in the North Moluccas by two endemic subspecies, is traded in relatively low numbers.

\section{Distribution, habitats and life history of White Cockatoo}

Cacatua alba is endemic to the North Moluccan islands of Halmahera, Bacan, Kasiruta and Mandiole. Specimens from both Bisa and Obi seem most likely to have derived from captive birds, or a feral population on Bisa, now extinct. In 1985 Smiet (1985) reported that $C$. alba was locally common on Halmahera. On Bacan the species was said by local people to have declined owing to trapping between the early and mid-1970s and 1985 (Milton and Marhadi 1987).

Populations of $C$. alba have probably been trapped for trade for many decades. In the last decade, following the opening up of forest by logging activities, this trapping may have become intensive, at least on a local level.

Cockatoos were found to occur in both primary and logged forests, and frequently to visit trees at the forest edge or tall trees within recently cleared land. In general, C. alba appears to favour flat or gently sloping areas in lowland areas, being scarce on steep slopes. Cockatoos were not observed above c.600 $\mathrm{m}$, and on Bacan they were found to be scarce above $300 \mathrm{~m}$. Indeed, cockatoos appeared to be absent from the steep primary forest slopes of Mount Sibela, suggesting that this nature reserve of $400 \mathrm{~km}^{2}$ may protect insufficient cockatoo habitat to support a viable population. In contrast, cockatoos were relatively common between $300 \mathrm{~m}$ and $500 \mathrm{~m}$ on the nearby island of Kasiruta, at a site with more gently sloping land than those sites at similar altitude visited on Bacan.

C. alba was primarily observed in pairs, or in small groups. Occasionally, loose flocks of up to 11 individuals were observed. They were most frequently observed in the canopy and emergent strata, though a few observations were observed at lower levels.

C. alba is a cavity-nesting species, and all available information suggests that only holes in the largest forest trees are suitable. Two probable nest-sites were observed during the surveys on Bacan in October and November 1991, one at $90 \mathrm{~m}$ altitude at the edge of recently cleared land bordering primary forest, the other in logged forest at $70 \mathrm{~m}$ altitude, inland from Yaba. Nest-holes were situated at points where large branches had broken off the main trunk. Loggers occasionally find parrots, including C. alba, in commercially valuable trees that they fell, such as Anisoptera (Dipterocarpaceae). Trappers in Halmahera had a young bird taken from a nest in a Canarium tree in August.

Villagers in Halmahera claimed that cockatoo nests contained eggs in May. A young cockatoo found on Bacan was probably taken from the nest in March or April. Smiet (1985) observed several breeding pairs on Bacan in April 1981. These records all strongly suggest that $C$. alba is a seasonal breeder and that the breeding season begins during the early part of the year.

Wild-caught birds do not breed until they are six years old (A. de Dios verbally 1991). Clutch-size of C. alba in captivity is reported to be two, occasionally three, 
and incubation takes $25-28$ days. Indonesians I interviewed reported that nests contained one or two juveniles. In captivity $C$. alba can live at least 40 years, and great longevity is also likely to be the rule rather than the exception in the wild.

C. alba appears to feed primarily on the seeds of arborial fruits. Bark-peeling behaviour observed on Bacan and frequent investigations of clumps of epiphytic vegetation suggest that it may also eat some larger invertebrates.

\section{Distribution, habitats and life history of Chattering Lory}

Lorius garrulus is endemic to the North Moluccas, where three subspecies are distributed throughout the large islands and their satellites. The subspecies confined to Obi and Bacan, L. g. flavopalliatus, is distinctive, with a large bold yellow mantle patch. In 1945 L. garrulus was reported to be the commonest parrot on Morotai and Rau (Lendon 1946), and was still locally common on Morotai and in other parts of its range in 1980-1981 (Smiet 1985). However, in 1985 Milton and Marhadi (1987) rarely encountered L. g. flavopalliatus on Bacan, and concluded that it was an uncommon species which might soon become rare.

Although previously reported to be a coastal bird (Smiet 1985, Inskipp et al. 1988), L. garrulus was found primarily to be a forest species. While tolerant of logging, it does not normally frequent agricultural land. It was virtually always observed in pairs. It is primarily a canopy species, but occasionally descends to the lower canopy to feed.

L. garrulus is nectarivorous, feeding on nectar and/or pollen. Some accounts indicate that it feeds on the flowers of coconuts along the coast, but this behaviour was not observed, suggesting that it is seasonal, or that populations have declined in coastal areas, as proposed by Forshaw (1989). However, on Obi one informant claimed that $L$. garrulus visited coastal coconuts during prolonged dry seasons.

On several occasions on Bacan, pairs of L. garrulus were observed investigating potential nest-sites in logged forest at c. $140-370 \mathrm{~m}$ altitude. One site was in the top of a broken palm trunk. However, holes used by L. garrulus were typically in swellings on main trunks at c. $20-25 \mathrm{~m}$ in trees c. $30-35 \mathrm{~m}$ tall. On Obi, one fully fledged immature with two adults was observed at $550 \mathrm{~m}$ in primary forest in mid-February, a record which suggests that eggs were laid during September or October 1991.

The breeding season for L. garrulus may be different from that of other parrots such as $C$. alba. Breeding activity apparently begins some time in September or October (on Obi) and may continue until at least late February. Brood-size is usually two (Forshaw 1989), although only one chick may survive (Low 1988).

\section{Distribution, habitats and life history of Violet-necked Lory}

Eos squamata has a less restricted range than the other species considered in this paper. It occurs throughout the North Moluccas and on islands to the west of Irian Jaya. Birds entering trade through Ambon and Ternate appear to derive from the two North Moluccan subspecies E. s. riciniata and E. s. obiensis. E. squamata was recorded in all habitat types, including coastal coconut groves, 
mangrove and scrubby secondary growth. Although Smiet (1985) thought that E. squamata was commonest in coconut plantations, few were seen in this habitat during my survey.

Like L. garrulus, E. squamata is a brush-tongued nectarivore. Unlike L. garrulus, however, E. squamata is a species which forms relatively large flocks. Hence it was common in some areas but very rare in others. During the surveys, $E$. squamata was most frequently encountered in pairs or small flocks, and occasionally in groups of up to 25. E. squamata tended to be rarer at higher elevations during the period of the field surveys.

On Obi, a pair of E. squamata were seen investigating various cavities in two tall, leafless dead trees in primary forest at $730 \mathrm{~m}$ altitude. The holes that these birds were investigating were situated at points where branches had broken off major side branches at c. $25 \mathrm{~m}$ above the ground. Captive birds usually lay two eggs which are incubated for 27-28 days; the young leave the nest about 65 days later (Low 1988). On Obi, villagers claimed that E. squamata bred in the same kinds of tall trees as L. garrulus, and laid one or two eggs.

\section{A note on the Eclectus Parrot}

Although the Eclectus Parrot is not considered in detail here, its populations may be highly susceptible to exploitation because of their habitat preferences.

Eclectus roratus vosmaeri, confined to the North Moluccan islands, was found to be abundant on islands visited by Smiet (1985) between 1979 and 1981. It inhabits coastal areas, mangroves, plantations and secondary forests. Smiet found it to be rare in primary forests, but my observations suggested that many individuals roost in inland forests, both logged and primary, up to at least $400 \mathrm{~m}$. These birds fly to lowland feeding areas at first light and return at dusk, travelling several or many kilometres in doing so. Many birds congregate in gardens, where they are reported by villagers to feed on maize, bananas and other fruits. This apparent attraction to gardens makes $E$. roratus an easy species to catch.

On Halmahera and Bacan Eclectus were estimated to be as common or commoner than $C$. alba in most areas visited. However, on Obi E. roratus was very rare. A villager of Kelo reported that this species was so common 40 years ago that crops had to be guarded against its depredations, but that it was now rare as a consequence of past trapping. If true, this illustrates its vulnerability to exploitation, and suggests that once populations have declined dramatically they may be unable to recover.

There is no doubt that many trappers still catch $E$. roratus, but at the same time they are dissuaded by the fear of reprisals from the authorities, since it is protected under Indonesian law. Another consideration is probably that E. roratus is less popular as a pet and of less value than other parrots such as C. alba and $L$. garrulus, which are not protected. Hence trappers would rather concentrate on these latter species despite the relative ease of trapping $E$. roratus. 


\section{Parrot population surveys, 1991-1992}

\section{Survey areas and methods}

I conducted surveys on Bacan, Kasiruta, Halmahera and Obi between 24 October 1991 and 24 February 1992. Figures 1 and 2 identify the main study sites on these islands, most of which are still forest-covered; for example, $88.5 \%$ of the total area of Morotai, Halmahera and Bacan (Figure 2). However, these forests are rich in economically valuable timbers and exploitation by logging companies is now intensive. Logging roads provide easy access for parrot trappers to formerly inaccessible sites, whilst commercial tree species exploited in logging concessions are often important as providers of breeding sites for parrots.

A variable circular plot (VCP) method was used to provide the baseline data for estimating population densities of parrots at each site. Variable-distance line transects were also walked at most sites, although the differences in terrain at different sites meant that my ability to detect parrots along transects varied between sites.

The survey areas were defined according to habitat type. "Primary forest" was forest that had not been commercially exploited. "Logged forest" was forest that had been selectively logged, and was divided into areas that had been logged within the last two years ("recently logged") and those that were logged more than two years previously ("old logged").

\section{Data analysis}

Data collected during this project were analysed using "DISTANCE" (Laake et al. 1991). This computer programme provides an analysis of distance sampling data for biological populations, although in some instances so few observations of certain parrot species were made that data could not be used by the programme. In these cases, population density estimates are based on a crude evaluation of VCP and transect data.

In the case of $C$. alba, birds detected during flight were included in the data analysis. Similarly for L. garrulus most flying birds were included; only those that were obviously flying through the area were excluded. However, only those E. squamata (a more highly mobile species) that were detected at rest were included in the DISTANCE analysis.

\section{Results of population surveys}

Extent of habitat types and population density estimates

Population estimates for Cacatua alba, Lorius garrulus and Eos squamata are based on the approximate area of broadly defined habitat types on the islands within their ranges, and on an appraisal of the extent of each habitat within the altitudinal range of each species. A major assumption in making these estimates was that C. alba, L. garrulus and E. squamata are fairly evenly distributed throughout their respective ranges and that population densities observed in different habitat types were typical of densities in areas of similar habitat that were not visited. 


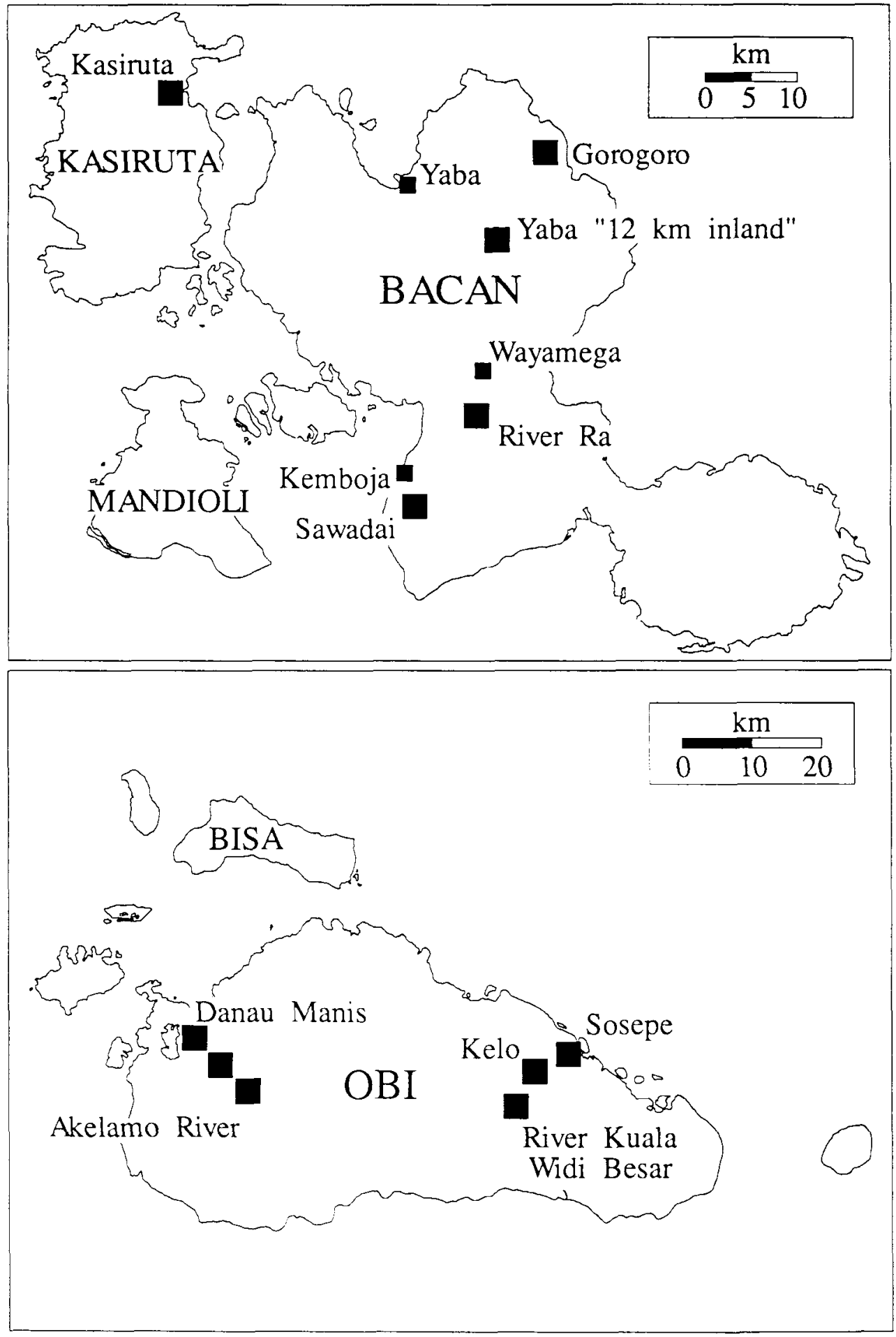

Figure 1. Study sites on Bacan (with Kasiruta) and Obi. Small squares denote minor study areas (VCP work not undertaken). 


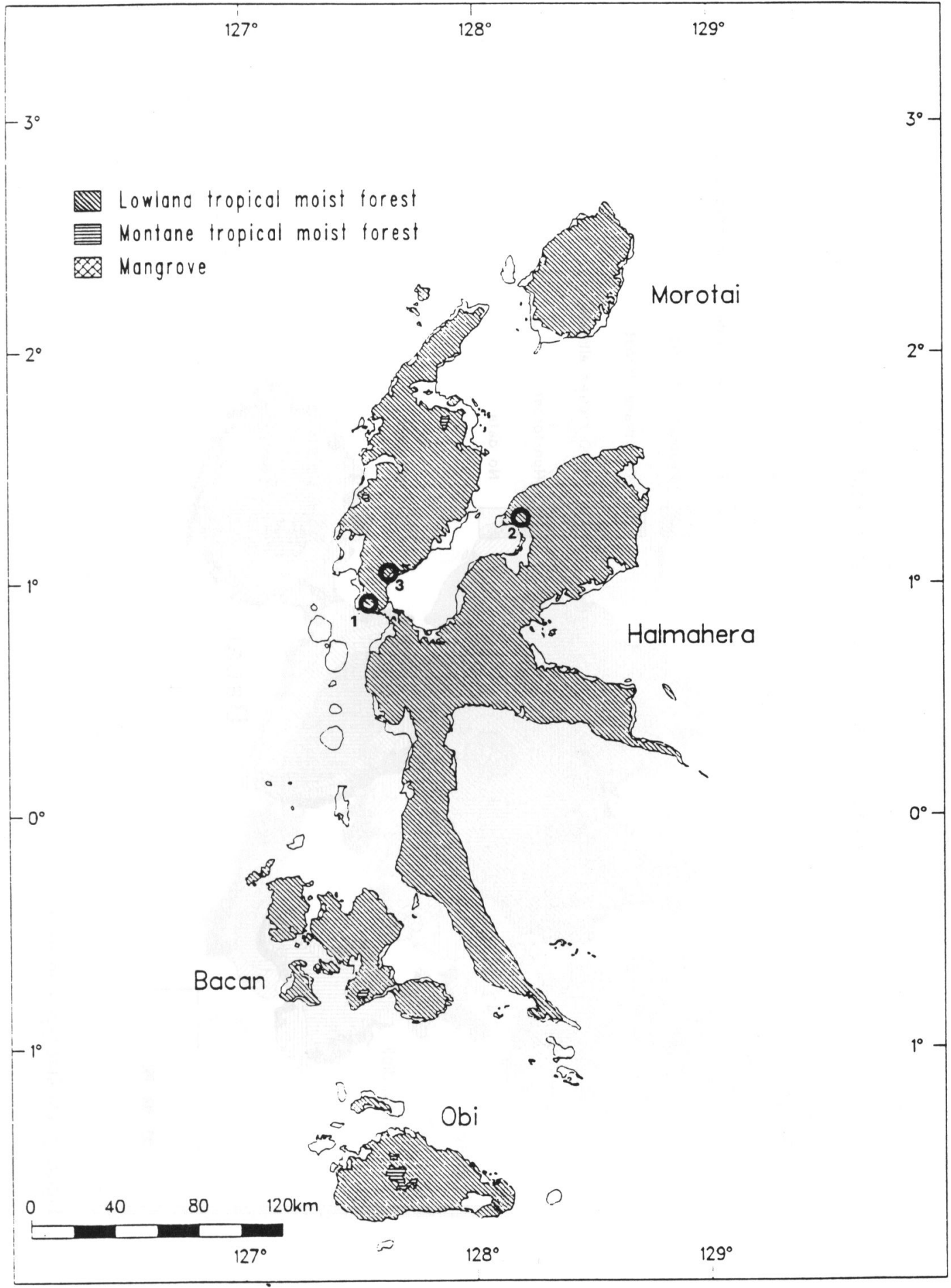

Figure 2. Forest cover in the North Moluccas, with the three main study sites on Halmahera: 1. Tanah Putih; 2. Foli; 3. Akelamo. 


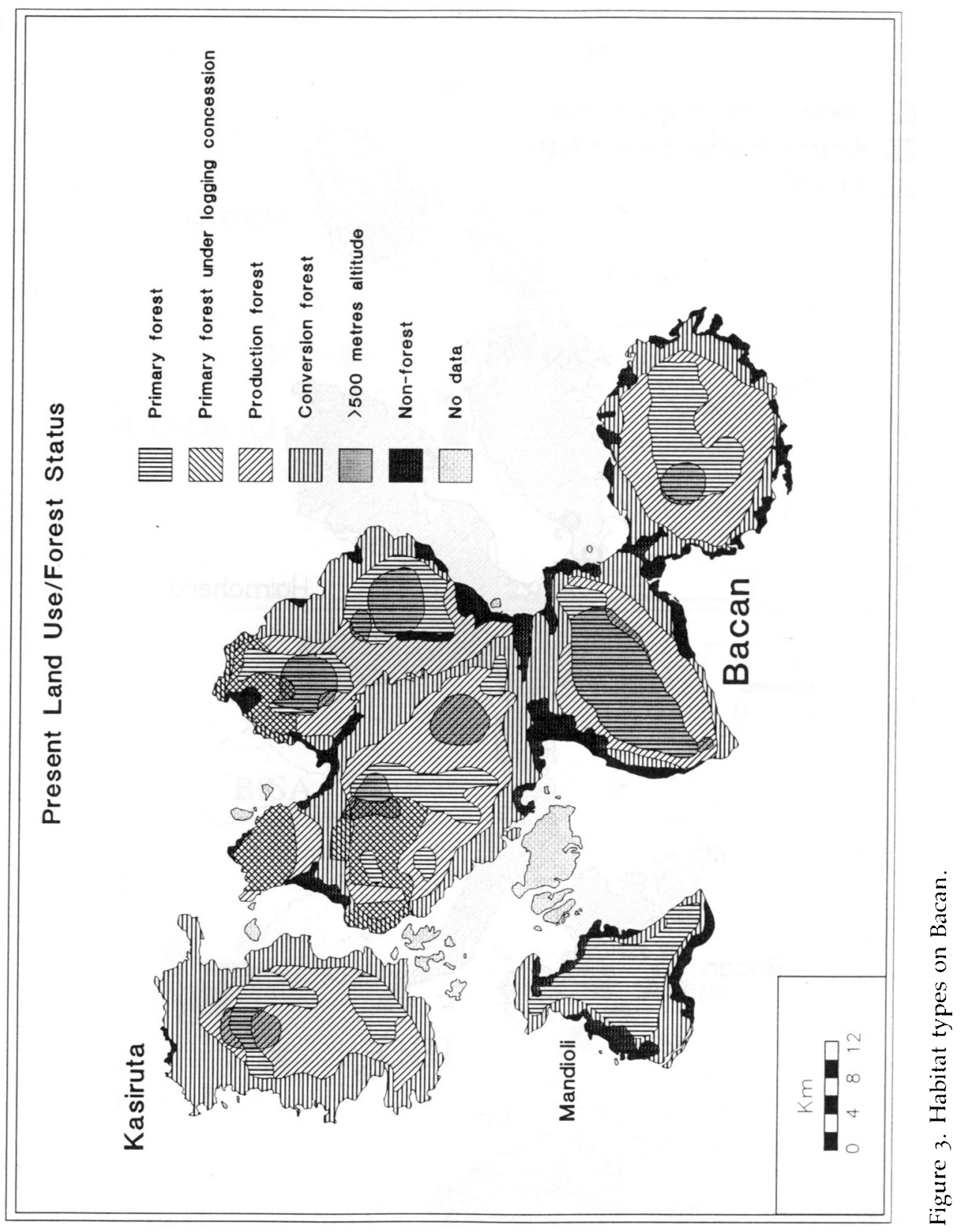




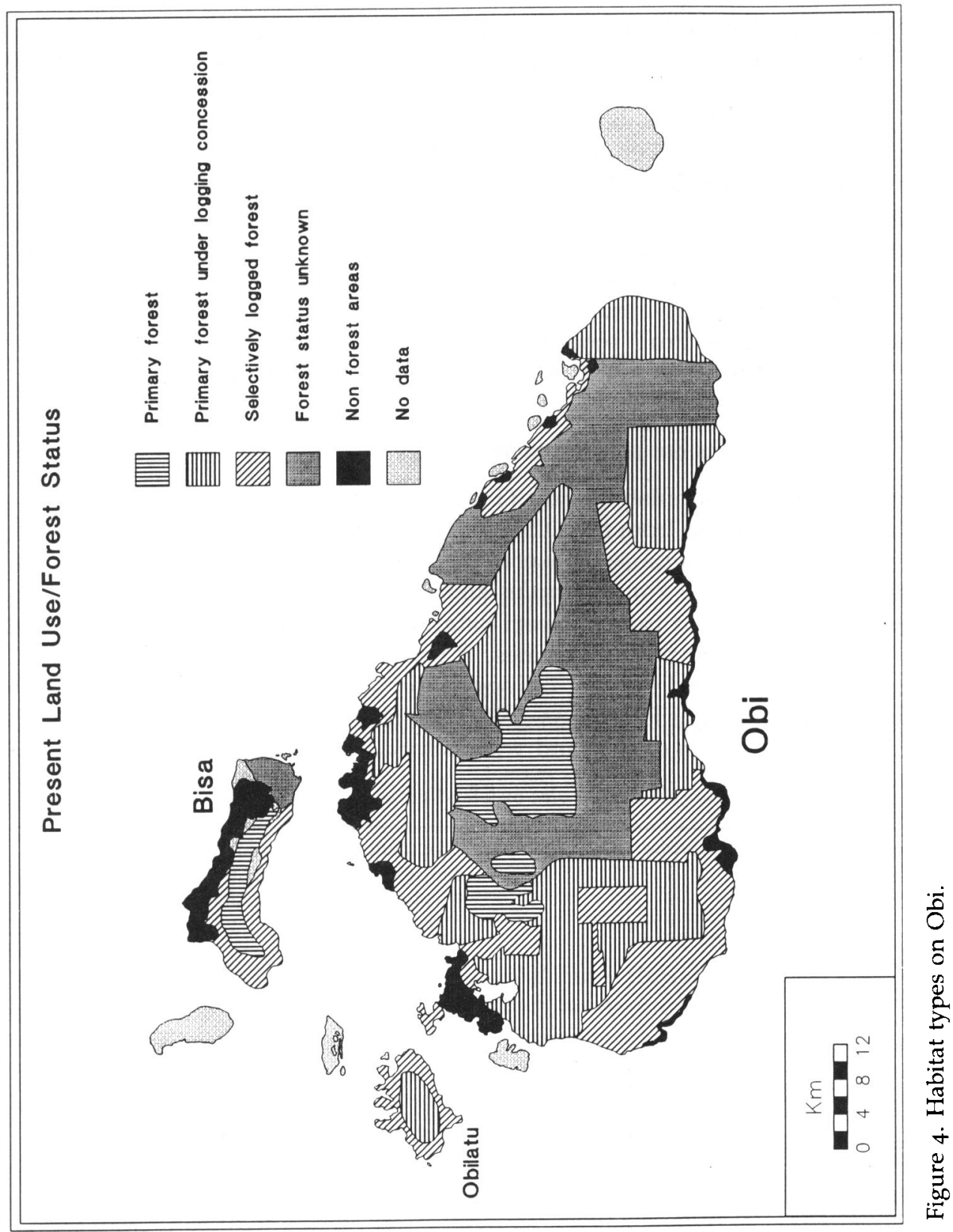


Maps of present land use and forest status (RePPProT 1991) form the basis for habitat classifications used in this study. The relevant RePPProT maps were based on aerial photography from the period 1976-1978 and Landsat imagery from 1972-1973, though the latter source provided incomplete coverage. The present extent of broadly defined habitat types on Bacan and Obi was determined from maps showing logging concessions from the Department of Forestry.

The areas of different habitat types on Bacan and Obi mapped during this study (Figures 3 and 4 ) were digitized by the World Conservation Monitoring Centre (WCMC). For Halmahera and Morotai, insufficient data were available to update the RePPProT maps. Therefore the extent of forest cover (Figure 2) was estimated from maps in Collins et al. (1991). Figures 3 and 4 show estimated extent of land under different types of land use on Bacan (Figure 3) and Obi (Figure 4). The data derive from the Regional Physical Planning Programme for Transmigration (RePPProT 1990) and an interpretation of maps prepared by various logging companies now active in the North Moluccas.

\section{Estimating North Moluccan parrot population sizes}

Estimates of parrot population sizes (Tables 1-3) used pooled site-specific density estimates obtained from the DISTANCE programme. For C. alba, only VCP estimates were used because transects were considered a less reliable method of estimating densities. For L. garrulus and E. squamata, means of all estimates, including those derived from transect data, were calculated.

In order to arrive at these estimates, it was assumed that $10 \%$ of all forests are on steep slopes and that $5 \%$ of logged forests fall into the recently logged category. Using these assumptions, minimum and maximum population densities for each species on each island were calculated (Tables 1-3).

Table 1. Population estimate for Cacatua alba by island group

\begin{tabular}{|c|c|c|c|c|c|}
\hline Habitat type & Habitat subtype & Area $\left(\mathrm{km}^{2}\right)$ & $\begin{array}{l}\text { Population } \\
\text { density used } \\
\text { in calculation }\end{array}$ & $\begin{array}{l}\text { Minimum } \\
\text { estimate of } \\
\text { population }\end{array}$ & $\begin{array}{l}\text { Maximum } \\
\text { estimate of } \\
\text { population }\end{array}$ \\
\hline \multicolumn{6}{|c|}{ BACAN/KASIRUTA/MANDIOLE } \\
\hline Primary forest & Undulating & 460 & $8.6-18.0$ & 3,956 & 8,280 \\
\hline Primary forest & Steep slopes & 115 & $1.0-2.5$ & 115 & 287 \\
\hline Logged forest & Recently & 72 & $7 \cdot 1-14 \cdot 5$ & 510 & 1,044 \\
\hline Logged forest & Old & 1,375 & $1.9-14.2$ & 2,612 & 19,525 \\
\hline Non-forest & & 50 & $0.5-3.3$ & 25 & 166 \\
\hline \multicolumn{4}{|c|}{ Population estimates for Bacan Island Group } & 7,220 & 29.300 \\
\hline \multicolumn{6}{|c|}{ HALMAHERA ISLAND GROUP } \\
\hline Forest & All & $11,800-12,600^{\mathrm{a}}$ & $3 \cdot 6-14 \cdot 5^{\mathrm{b}}$ & 42,480 & 182,700 \\
\hline Non-forest & All & $130^{\circ}$ & $0.5-3 \cdot 3$ & 65 & 429 \\
\hline \multicolumn{4}{|c|}{ Population estimate for Halmahera Group } & 42,545 & 183,129 \\
\hline \multicolumn{4}{|c|}{ Total world population estimate } & 49,765 & 212,430 \\
\hline
\end{tabular}

\footnotetext{
assumes that $20-25 \%$ of forest on Halmahera is uninhabited by C. alba due to altitude or forest type.

${ }^{b}$ Population density estimates derive from overall minimum and maximum values for forest habitats in Bacan.

c assumes C. alba occupies $20 \%$ of non-forest habitats.
} 
Table 2. Population estimate for Lorius garrulus by island group

\begin{tabular}{|c|c|c|c|c|c|}
\hline Habitat type & Habitat subtype & Area $\left(\mathrm{km}^{2}\right)$ & $\begin{array}{c}\text { Population } \\
\text { density used } \\
\text { in calculation }\end{array}$ & $\begin{array}{l}\text { Minimum } \\
\text { estimate of } \\
\text { population }\end{array}$ & $\begin{array}{l}\text { Maximum } \\
\text { estimate of } \\
\text { population }\end{array}$ \\
\hline \multicolumn{6}{|c|}{$\overline{\text { BACAN/KASIRUTA/MANDIOLE }}$} \\
\hline Primary forest & Undulating & 700 & $0.5-9.4$ & 350 & 6,580 \\
\hline Primary forest & Steep slopes & $7^{8}$ & $2.2-7.2$ & 172 & 562 \\
\hline Logged forest & Recently & 75 & $3.9-8.4$ & 293 & 630 \\
\hline Logged forest & Old & 1432 & $2.6-17.1$ & 3,723 & 24,487 \\
\hline Non-forest & & 25 & 0.3 & 8 & 8 \\
\hline \multicolumn{4}{|c|}{ Population estimates for Bacan Island Group: } & 4,546 & 32,267 \\
\hline \multicolumn{6}{|c|}{ OBI ISLAND GROUP } \\
\hline Primary forest & & 1050 & $3.1-7 \cdot 0$ & 3,255 & 7,350 \\
\hline Logged forest & Recently & 35 & $1.0-4.2$ & 35 & 147 \\
\hline Logged Forest & Old & 672 & $2.4-4.9$ & 1,613 & 3,293 \\
\hline Forest & Status unknown & 763 & $2.4-7.0$ & 1,831 & 5,342 \\
\hline Non-forest & & 40 & 0.3 & 12 & 12 \\
\hline \multicolumn{4}{|c|}{ Population estimates for Obi Island Group } & 6,746 & 16,144 \\
\hline \multicolumn{6}{|c|}{ HALMAHERA ISLAND GROUP } \\
\hline Non-forest & All & $65-162^{b}$ & 0.3 & 20 & 49 \\
\hline Forest & All & 15,600 & $2.0-14.1$ & 31,200 & 219,960 \\
\hline \multicolumn{4}{|c|}{ Population estimates for Halmahera Group } & 31,220 & 220,009 \\
\hline \multicolumn{6}{|l|}{ MOROTAI } \\
\hline Non-forest & All & $8-19^{b}$ & 0.3 & 2 & 6 \\
\hline Forest & All & 1,923 & $2.0-14 \cdot 1^{a}$ & 3,846 & 27,114 \\
\hline \multicolumn{4}{|c|}{ Population estimate for Morotai } & 3,848 & 27,120 \\
\hline \multicolumn{4}{|c|}{ Total world population estimate } & 46,360 & 295,540 \\
\hline
\end{tabular}

a Population density estimates derive from overall minimum and maximum values for forest habitats in Bacan and Obi.

b Assumes that L. garrulus occupies $10-25 \%$ of non-forest habitat.

\section{Trade: centres and significance}

Parrot trapping in the North Moluccas

Most information concerning parrot trappers came from interviews of trappers on Bacan. On Bacan trappers can be divided into two categories: those that are "professional", parrots providing their primary or major source of income, and those that are "casual", involving the occasional catching of parrots. Interviews suggested that over a hundred people regularly trap parrots on Bacan, though probably only c. 30 are professionals (virtually all villagers from Desa Gandasuli).

Professional parrot trappers from Gandasuli work in all parts of Bacan and satellite islands. Trappers on Bacan claimed to sell their parrots to local suppliers, though at least one trapper from Gandasuli was said to send his birds to Obi, whilst others may be involved in the supposed illegal trade discussed later in this paper.

In the North Moluccas, the target parrot species are attracted with decoy conspecifics and usually caught with gum. The gum adheres to the flight feathers rendering parrots incapable of flight. Gum is cleaned off the plumage 
Table 3. Population estimate for Eos squamata by island group

\begin{tabular}{|c|c|c|c|c|c|}
\hline Habitat type & Habitat subtype & Area $\left(\mathrm{km}^{2}\right)$ & $\begin{array}{c}\text { Population } \\
\text { density used } \\
\text { in calculation }\end{array}$ & $\begin{array}{l}\text { Minimum } \\
\text { estimate of } \\
\text { population }\end{array}$ & $\begin{array}{l}\text { Maximum } \\
\text { estimate of } \\
\text { population }\end{array}$ \\
\hline \multicolumn{6}{|c|}{ BACAN/KASIRUTA/MANDIOLE } \\
\hline Primary forest & All & 728 & $2.1-7.2$ & 1,529 & 5,242 \\
\hline Logged forest & Recently & 75 & $2.3-26.5$ & 173 & 1,988 \\
\hline Logged forest & Old & 1,432 & $3 \cdot 8-7 \cdot 4$ & 5,442 & 10,597 \\
\hline Non-forest & & 200 & $4.8-42.2$ & 960 & $8,44^{\circ}$ \\
\hline \multicolumn{4}{|c|}{ Population estimates for Bacan Island Group } & 8,104 & 26,267 \\
\hline \multicolumn{6}{|c|}{ OBI ISLAND GROUP } \\
\hline Primary forest & & 1,050 & $2.1-7.2$ & 2,205 & 7,560 \\
\hline Logged forest & Recently & 35 & $3 \cdot 7-12.6$ & 129 & $44^{1}$ \\
\hline Logged Forest & Old & 672 & $11.0-36.5$ & 7,392 & 24,528 \\
\hline Forest & Status unknown & 763 & $2.1-36.5$ & 1,602 & 27,850 \\
\hline Non-forest & & 100 & $4.8-42.2$ & 480 & 4,220 \\
\hline \multicolumn{4}{|c|}{ Population estimates for Obi Island group } & 11,808 & 64,599 \\
\hline \multicolumn{6}{|c|}{ HALMAHERA ISLAND GROUP } \\
\hline Non-forest & All & 647 & $4.8-42.2$ & 3,106 & 27,303 \\
\hline Forest & All & 15,600 & $2.7-17 \cdot 9$ & 42,120 & 279,240 \\
\hline \multicolumn{4}{|c|}{ Population estimate for Halmahera Group } & 45,226 & 306,543 \\
\hline \multicolumn{6}{|l|}{ MOROTAI } \\
\hline Non-forest & All & 77 & $4.8-42.2$ & 370 & 3,249 \\
\hline Forest & All & 1,923 & $2.7-17 \cdot 9^{\mathrm{a}}$ & 5,192 & 34,422 \\
\hline \multicolumn{4}{|c|}{ Population estimate for Morotai } & 5,562 & 37,671 \\
\hline \multicolumn{4}{|c|}{ Total North Moluccan population estimate } & 70,700 & 435,080 \\
\hline
\end{tabular}

a Population density estimates derive from overall minimum and maximum values for forest habitats in Bacan and Obi.

with kerosene or petrol. Young C. alba, E. roratus and L. garrulus are also occasionally taken from nests, usually by felling the nest-tree.

\section{Suppliers and exporters of North Moluccan parrots}

There are at least two tiers of suppliers involved in the trade of North Moluccan parrots: those on the various islands, and those in Ambon and Ternate. Suppliers on Bacan send their parrots to suppliers in Ternate and Ambon, who in turn sell parrots to exporters in Jakarta, Surabaya and Denpasar. In 1990 one trader in Ambon was sending birds directly to the U.S.A. via Biak. Some suppliers trade illegally, frequently using permits more than once, or using letters of recommendation rather than real permits, and they may well disregard numbers or species composition on permits.

\section{Parrot species trapped in the North Moluccas}

Most trappers in the North Moluccas specialize in catching L. garrulus and C. $a l b a$, though at certain times of the year $E$. squamata becomes easy to catch and is then sought. A few Red-flanked Lorikeets Charmosyna placentis may also be caught, but this is not usually a target species. Small numbers of $E$. roratus are caught but they cannot be sold legally. The Great-billed Parrot Tanygnathus 
megalorynchos was seen in captivity only twice, and trappers very rarely catch this species, or Red-cheeked Parrot Geoffroyus geoffroyi. Most trappers were unaware of the presence of Moluccan Hanging-parrot Loriculus amabilis on the islands. On Halmahera, the Moluccan King-parrot Alisterus amboinensis hypophonitus is said to be caught in small numbers, but no bird of this subspecies was seen in captivity or on sale in markets visited.

\section{Mortality of parrots in trade}

Parrots die at all stages of trade, though Moluccan parrots vary greatly in their hardiness. Although anecdotal, information on the levels of mortality prior to shipment to other destinations was obtained from a number of people involved in the parrot trade. Species which reportedly die easily, such as Geoffroyus geoffroyi and Alisterus amboinensis, are traded at very low levels. Tanygnathus megalorynchos is said to fight if kept in groups, often causing fatal injuries. Cacatua alba, Lorius garrulus and Eos squamata are hardier, though mortality is certainly not insignificant.

Birds which die after capture are discarded and not counted for the purposes of trade statistics. Anecdotal evidence obtained from numerous interviews suggest that something in the order of $15-20 \%$ of L. garrulus, 7-10\% of C. alba and probably more than $25 \%$ of E. squamata die prior to shipment to other destinations within Indonesia.

\section{Levels of parrot trade in the North Moluccas}

Since 1985 , the level of international trade in C. alba has declined. In contrast, that in E. squamata has remained relatively constant, whilst exports of L. garrulus have gradually increased (Edwards and Nash 1992). Table 4 shows the current level of trade and quotas set for these species as reported by PHPA (Directorate for Forest Protection and Nature Conservation).

It should be noted that quotas are established for the capture of wild parrots, and not just for export. However, as reported elsewhere (Callister 1989, Nash 1990) the psittacine trade in Indonesia is poorly monitored and the quota system is currently inadequate. One investigation (Nash 1992) suggested that, at best, official records are representative of one-quarter to one-half of the actual trade.

It is therefore not possible to assess the exact numbers of any particular species trapped in any particular year merely by looking at permit data. During the course of this project an attempt was made to assess the real levels of

Table 4. Annual quotas and numbers of birds recorded in trade by Department of Forestry, Ambon

\begin{tabular}{|c|c|c|c|c|c|c|c|}
\hline \multirow{5}{*}{$\begin{array}{l}\text { Cacatua alba } \\
\text { Lorius garrulus }\end{array}$} & \multicolumn{3}{|c|}{1990} & \multicolumn{3}{|c|}{1991 (incomplete) } & \multirow[t]{2}{*}{ Total 1990} \\
\hline & Quota & Export & Pets & Quota & Export & Pets & \\
\hline & 6,750 & 6,479 & $12 I$ & 4,500 & $3,174^{a}$ & 1.18 & 6,600 \\
\hline & 5,900 & 4,727 & 1,408 & 5,900 & $3.526^{\mathrm{a}}$ & 1,432 & 6,135 \\
\hline & 2,400 & 2,146 & 6 & o & $0^{3}$ & 14 & 2,152 \\
\hline
\end{tabular}

Numbers of birds exported in first six months of 1991. The number of pets exported for the domestic market (from Ambon and Ternate) was estimated using mean monthly figures because data from Ternate were incomplete and data from Ambon were not available for December 1991. 
recent trade in North Moluccan parrots. Data on trapping and trade of psittacine species were gathered from PHPA and the Department of Forestry in Ambon and Ternate, from interviews with individuals involved in trade, and by visits to various markets in Indonesia.

Insufficient data were collected on Halmahera or Obi to assess the levels of trade in parrots, but many trappers and suppliers were visited and interviewed on Bacan. Observations of birds in holding cages on Bacan during this survey suggested that about $50 \%$ of the parrots exported are L. garrulus and $25 \% \mathrm{C}$. alba. At other times of the year different species may be more predominant. Based on the interviews conducted and observations on Bacan, a preliminary estimate of the total number of parrots entering trade from Bacan, Kasiruta and Mandiole has been made (Table 5).

\section{Overall parrot trade in the Moluccas: total numbers caught}

Whilst the majority of parrots caught are destined for international trade, significant numbers also enter the domestic market. The number of parrots entering the domestic market as pets which remain within the Moluccas is unknown, but permits are required to take "souvenirs" (pets) outside the province. These permits form the basis of the statistics compiled by the Forestry Department, Ambon (Table 4). Despite the paucity of data relating to domestic trade, an attempt is made below to estimate the number of birds which probably enter the market each year.

Lorius garrulus is one of the most important species in domestic trade in Indonesia. Of 113 pet parrots seen on these islands, $68(60.2 \%)$ were L. garrulus. Even considering Ambon and Ternate alone, 33.3\% of pets were this species.

Of 381 parrots of 19 species observed at markets in Indonesia, $116(30.5 \%)$ were $L$. garrulus (the commonest species in the sample). In contrast, Cacatua alba was represented by eleven pets $(9.7 \%)$ and 44 individuals $(11.5 \%)$ in the market sample. Cockatoos were generally rare in markets far from the source: only two C. alba, or $1.2 \%$ of parrots on sale, were seen in the Java and Bali markets visited. In contrast, Moluccan lories formed $42.5 \%$ of parrots on sale in the same markets, and L. garrulus was the fourth commonest species overall (11.2\%). In the domestic market, L. g. flavopalliatus was the commonest subspecies identified, forming $64 \%$ of birds.

On Bacan there is a large discrepancy between the number of permits issued to capture parrots and the number that are actually caught. In part this is probably because some permits issued for Obi are used to catch birds on Bacan.

Table 5. Estimates of trade in parrots originating from Bacan, Kasiruta and Mandiole for 199x

\begin{tabular}{lcccc}
\hline Species & $\begin{array}{c}\text { Bacan catch } \\
\text { quota, 1991 }\end{array}$ & Observed $^{\text {a }}$ & Minimum & Maximum \\
\hline Lorius garrulus & 250 & 2,088 & 4,450 & 6,760 \\
Cacatua alba & 200 & 960 & 2,355 & 3,700 \\
Eos squamata & 125 & 816 & 3,995 & 6,570 \\
Eclectus roratus & 0 & 192 & 455 & 580 \\
\hline
\end{tabular}

a Observed is based on numbers of birds seen in holding cages during the period of fieldwork, whilst figures for minimum and maximum are estimates using information from interviews. 
Such birds are then moved to Ambon via Obi. However, this inter-island movement of birds, while making it more difficult to identify the real source of birds, is insufficient in itself to explain the discrepancy.

If such discrepancies are typical throughout the North Moluccan region, then the issue of permits in Ambon for the capture of 3,200 C. alba, 3,200 L. garrulus, and 1,425 E. squamata during 1991 suggests that minimum numbers of parrots caught include 9,600 L. garrulus, 5,120 C. alba and 2,850 E. squamata. These estimates derive from an assumption that the ratio between permits issued and estimates of birds trapped is indicative of real trade levels. The estimates are considered conservative, in particular for the two lories.

Estimates can also be made by starting with the number of birds exported and considering the proportion of birds dying and those entering domestic trade. In doing so, similar figures are arrived at (Table 6). The estimate of 9,600 L. garrulus caught in 1991 does not, therefore, seem unreasonable. Using similar logic to calculate estimates in this way for $C$. alba provides an estimate of $7,110-$ 7,500 birds caught in 1990 and 3,482-3,674 during the first half of 1991 . For $E$. squamata riciniata/obiensis a similar calculation suggests that 2,980 individuals were trapped in 1990.

\section{Legal and illegal trade in North Moluccan parrots}

There is a great deal of evidence to suggest that much of the trade in parrots from the North Moluccas occurs outside of the quota system. The numbers of parrots entering international trade legally are recorded by PHPA in Jakarta, and documented by importing countries that are party to CITES. A comparison of these figures shows that the quotas set by the government of Indonesia are frequently exceeded (Edwards and Nash 1992). Illegal international trade is also responsible for the export of additional parrots.

That illegal trade continues is well recognized by PHPA and individuals involved in the parrot trade. There is rumoured to be significant illegal trade in parrots with Singapore, involving Butonese traders operating from the port of Wangi-Wangi (South Sulawesi). Other parrots are sold in small numbers to crews of foreign fishing vessels. It is estimated that at least one thousand and possibly several thousand parrots comprised of L. garrulus, E. squamata, C. alba and $E$. roratus leave Indonesia by these routes.

Table 6. Estimates of minimum total numbers of three species of North Moluccan parrots caught in 1991, and final destination (domestic vs. international markets)

\begin{tabular}{lccc}
\hline & Cacatua alba & Lorius garrulus & Eos squamata \\
\hline Total caught & $5,120-7,500$ & $9,600-9,927$ & $2,850-2,980$ \\
Number dying prior to shipment & $358-750$ & $1,440-1,985$ & $712-745$ \\
Domestic trade $^{a}$ & $187-386$ & $1,061-1,573$ & $284-291$ \\
Exported $^{b}$ & $3,984-6,955$ & $6,042-7,426$ & $1,814-1,984$ \\
\hline
\end{tabular}

a It is assumed that 300 L. garrulus, 200 E. squamata and 100 C. alba enter the domestic trade as locally kept pets each year.

b This figure includes illegal exports. 


\section{Discussion}

\section{Conservation status of North Moluccan parrots}

Current levels of exploitation of the three North Moluccan parrots examined in this paper suggest that overexploitation of C. alba and L. garrulus is occurring. Trappers may be removing in the order of $17 \%$ and $10 \%$ respectively of the world populations of these species. Modelling of population dynamics of parrots has suggested that even the capture of as few as $3 \%$ of parrot populations might lead to a gradual decline in numbers (Anon. undated).

Using criteria proposed by Mace and Lande (1991) to evaluate threats, C. alba and L. garrulus should be classified as Endangered. E. squamata riciniata and E. s. obiensis are still relatively common: trade levels are probably low compared to estimated population size, but it would be pragmatic to treat both as Vulnerable.

\section{Population estimates and monitoring population sizes}

Population estimates for all species are summarized in Table 7 . Whilst reasonable confidence can be placed in the population estimates for Bacan and Obi, those for Halmahera and Morotai are more tentative. The population densities used in estimating population sizes on these latter islands allow for a wide margin of error.

Milton and Marhadi (1987) investigated the parrot population of Bacan in 1985, and recommended revisiting the island at five-year intervals in order to ascertain trends in population status. Two criteria were suggested for use by future surveys as indicators of changes in abundance: the encounter rate of groups of parrots per hour, and the mean group-size.

Unfortunately, comparisons of parrot encounter rates between this survey and those of Milton and Marhadi (1987) are difficult to make because of inadequate documentation of their study sites, methods and results. In addition, habitats had been modified in the six-year period since their survey. The overall encounter rates computed from tables in Milton and Marhadi (1987) are lower than those obtained during this study. However, it is unlikely that this puzzling inconsistency is a consequence of a genuine increases in parrot population densities on Bacan. The fact that the two sets of surveys were conducted at different times of year, and that different areas were visited, may have influenced encounter rates and contributed to differences found.

Table 7. Population estimates by island group and subspecies for Cacatua alba, Lorius garrulus and the North Moluccan population of Eos squamata

\begin{tabular}{|c|c|c|c|c|c|}
\hline Species/subspecies & Morotai & Halmahera & Bacan & Obi & Total \\
\hline Cacatua alba & & $42,545-183,129$ & $7,220-29,300$ & & $49,765-212,430$ \\
\hline Lorius garrulus & & & & & $46,360-295,540$ \\
\hline L. g. garrulus & & $31,220-220,009$ & & & $31,220-220,009$ \\
\hline L. g. morotaianus & $3,848-27,120$ & & & & $3,848-27,120$ \\
\hline L. g. flavopalliatus & & & $4,546-32,267$ & $6,746-16,144$ & $11,292-48,411$ \\
\hline \multicolumn{5}{|c|}{ Eos squamata (North Moluccan population) } & $66,050-419,856$ \\
\hline E. s. riciniata & $5,562-37,671$ & $45,226-306,543$ & $8,104-26,267$ & & $58,892-370,481$ \\
\hline E. s. obiensis & & & & $11,808-64,599$ & $11,808-64,599$ \\
\hline
\end{tabular}


Moreover, data from this study show that mean group-size, the second of Milton and Marhadi's population-trend indicators, is independent of population density (correlation coefficients, $r$ : C. alba 0.19, L. garrulus 0.20, E. squamata 0.35). Hence the mean group-size of these three species cannot be used to assess changes in population density.

Analysis of the data collected during this survey is somewhat complex. It is therefore important that a relatively simple, standardized method of both data collection and interpretation be devised. Figures 5 and 6 indicate that encounter rates from VCP data-points could provide a basis for monitoring population change in forest habitats. These figures show that there is a significant positive relationship between the mean number of detections per VCP observation station (encounter rate) and the density estimate obtained from the same dataset.

Using graphs such as those of Figures 5 and 6, it could be possible for relatively inexperienced observers to make rough estimates of population density from their encounter rates and to document trends, provided that they follow set procedures and can competently identify parrot species by call as well as by sight. The graphs presented in this paper are tentative, being based on relatively small datasets, so it is not recommended to use these graphs in future surveys to calculate population densities; rather, intensive research should be carried out in order to provide more accurate graphs or to develop alternative tools to assist Indonesian fieldworkers. If more rigorously researched graphs can be constructed, and field tests show that they can be used as a simple tool to

\section{Cacatua alba}

\section{(D) Population density $\left(\right.$ no/ $\left.\mathrm{km}^{2}\right)$}

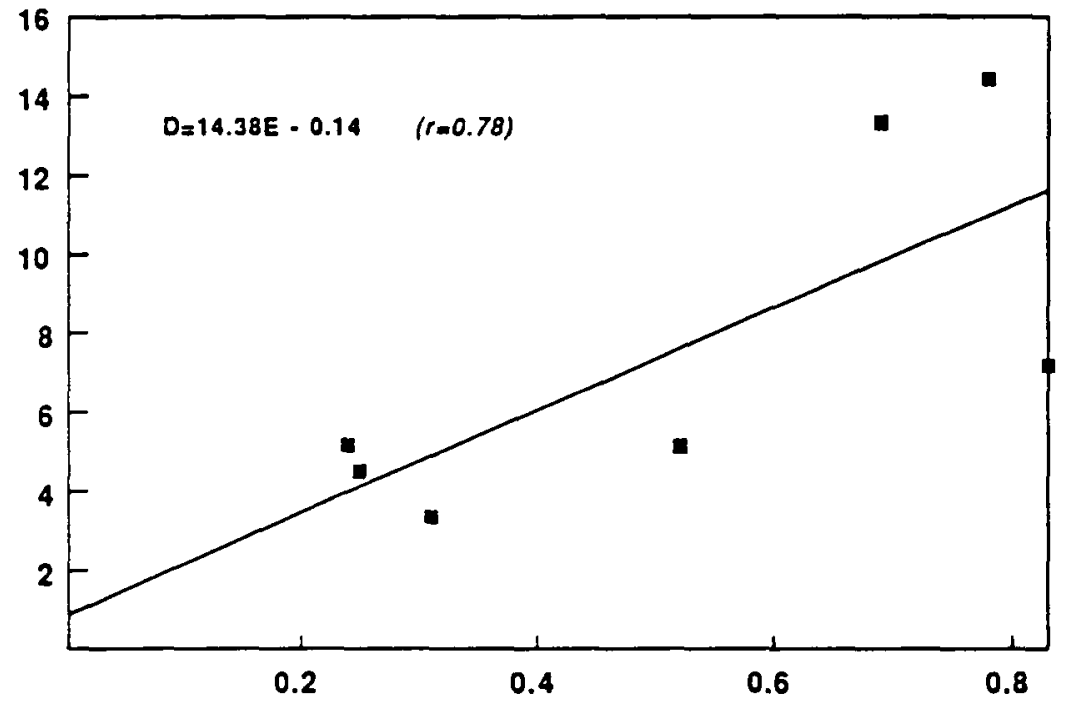

(E) Encounter Rate (groups/VCP station)

Figure 5. The relationship between encounter rates of Cacatua alba at VCP stations and estimated population density. 
estimate population sizes, regular surveys designed to monitor trends in parrot population size could be facilitated in terms of both cost and time.

It is imperative, however, that the data used to calculate such graphs should be based on far larger datasets than those presented here. A greater investment in time would be necessary. In particular, more repetitions of VCP stations and/or transects at each site would increase the accuracy of the encounter rates and population density estimates. Given more time, it would also be possible to increase the distance between VCP stations, and hence reduce any bias from counting parrots twice. Points of inflection calculated by the DISTANCE programme during data analysis suggest that 500-600 $\mathrm{m}$ would be a better distance between VCP stations.

Without the development of rapid evaluation techniques that could be used by relatively inexperienced observers, it seems unlikely that regular surveys could be conducted at sufficient sites to identify trends in parrot population sizes with confidence. The development of interpretative tools, such as the graphs suggested here, should be made a priority of management policy relating to the sustainability of the trade in Indonesian parrots. An alternative might lie in the development of user-friendly, menu-driven software for the analysis of VCP or transect data. Software development would probably have the advantage of providing more accurate estimates, but the level of training of individuals involved in the collection and analysis of data would need to be higher.

\section{Lorius garrulus}

(D) Population Density (no/km ${ }^{2}$ )

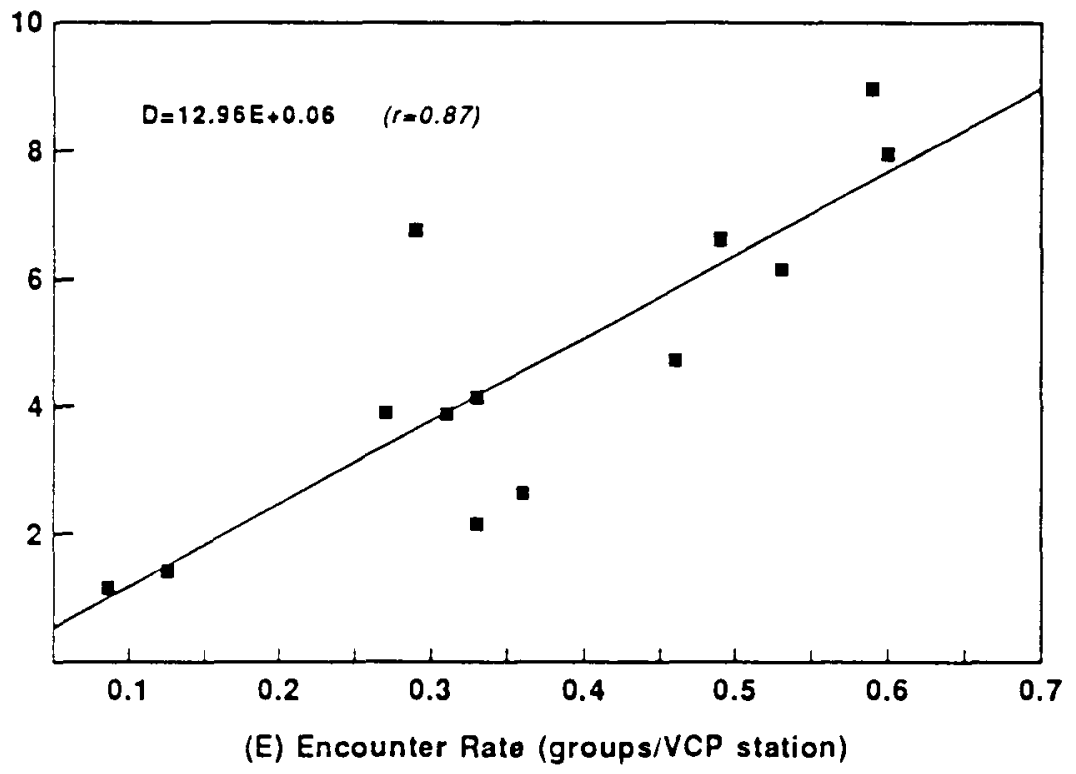

Figure 6. The relationship between encounter rates of Lorius garrulus at VCP stations and estimated population density. 


\section{Towards sustainability in North Moluccan parrot trade}

Sustainable populations of wildlife are those that are harvested at a rate equivalent to or less than the productivity of the population. In the long term, Indonesian parrots cannot be expected to survive if rates of harvest exceed rates of recruitment. It is therefore important, not only to conservationists, but also to traders, that the trade in parrots be regulated in such a way as to ensure sustainability.

For C. alba and L. garrulus, present trapping levels are unlikely to be sustainable. The following discussion evaluates the potential for setting sustainable quotas for these species and E. squamata.

The most essential components which need consideration are a knowledge of: (a) population size and age-structure, (b) population dynamics, (c) ranging behaviour, and (d) the effects of extraneous factors (such as logging activities or forest fires) which may influence these natural population processes. Unfortunately, many years of autecological research are necessary to elucidate even the most fundamental aspects of the population biology of long-lived parrots. At present, biological data are inadequate to predict, with confidence, a realistic upper limit of sustainable exploitation for the species under study.

In the short term a pragmatic approach must be taken in which estimates of minimum population size are used to set interim quotas. During this interim, attempts should be made to upgrade the very limited knowledge of population dynamics and ecology of the species concerned by initiating field research, with the aim of setting more realistic quotas. Monitoring changes in the size of wild populations should also be an integral component of the sustainable quota system, and redefining quotas in accordance with observed population trends will undoubtedly be necessary.

In the longer term, the possibility of changing the tradition of catching adults to one of taking nestlings or of removing and incubating eggs might be attempted. The harvesting of eggs or nestlings, a large proportion of which would have died naturally, would allow larger numbers of birds to be harvested, and provide a better end-product since hand-reared parrots make better pets (Beissinger and Bucher 1992). The introduction of new methods of harvesting would require major funding of a small number of nucleus projects which, if successful, could then be promoted elsewhere.

Trappers would need to be paid higher prices for these hand-reared birds to compensate, initially at least, for the likely decline in the numbers of birds that they are able to capture. In the long term, however, trappers could anticipate elevated rates of return from a system concentrating on the harvest of nestlings, particularly if nest-sites were found to be a limiting demographic factor for North Moluccan parrot species, and if these species could be encouraged to nest in man-made nest-sites. Beissinger and Bucher (1992, in press) document such a system.

Biological considerations form only part of the requirements of a sustainable system of harvesting. As pointed out by Edwards and Thomsen (1992), techniques for managing the wild bird trade in Indonesia must be improved if parrots traded in large volume are to be sustained in the long term. Strict policing, and the curtailment of illegal trade, are essential to the success of any 
harvesting system which aims to be sustainable. Cheating at any level of exploitation, by removing uncounted adults, would seriously compromise the sustainability of trade.

\section{Setting quotas}

With so little information on the biological parameters discussed above, the development of models designed to set sustainable quotas is unrealistic. However, reference to other models which have been developed are of interest because the results suggest that even low levels of trade are likely to cause population declines. One such model (Anon. undated), simulating the effects of trade on Red-fronted Macaws Ara rubrogenys, suggests that the annual capture of as few as $3 \%$ of the population would result in a decline from which recovery was not certain, even if all harvesting was suspended.

The setting of sustainable quotas for North Moluccan species must incorporate an allowance for the post-capture species-specific mortality and consideration of the illegal capture of birds. At present, quotas are exceeded largely because many trappers catch birds without permits. Until, therefore, active law enforcement curtails such trapping, and unless such trapping is allowed for in setting quotas, the goal of sustainability is unlikely to be realized.

Table 8 provides some suggested upper limits for interim quotas based on the premise that a $5 \%$ take of the minimum population estimate would not be large enough to cause overexploitation. It is important that quotas be set on an island basis, because if for instance half the total quota for $C$. alba were to be taken from Bacan, sustainability could not be guaranteed.

The interim quotas suggested in Table 8 are divided into two tiers, a catch quota which defines the total number of birds which should be caught, and an export quota for wild-caught birds. The catch quota is calculated as $5 \%$ of the minimum population estimate, reduced to allow for mortality (since birds which die are typically discarded) and illegal trade.

If future research and education programmes are able to reduce levels of mortality and law enforcement becomes more efficient, official capture quotas

Table 8. Suggested interim quotas for North Moluccan parrots by island (numbers are rounded to nearest ten)

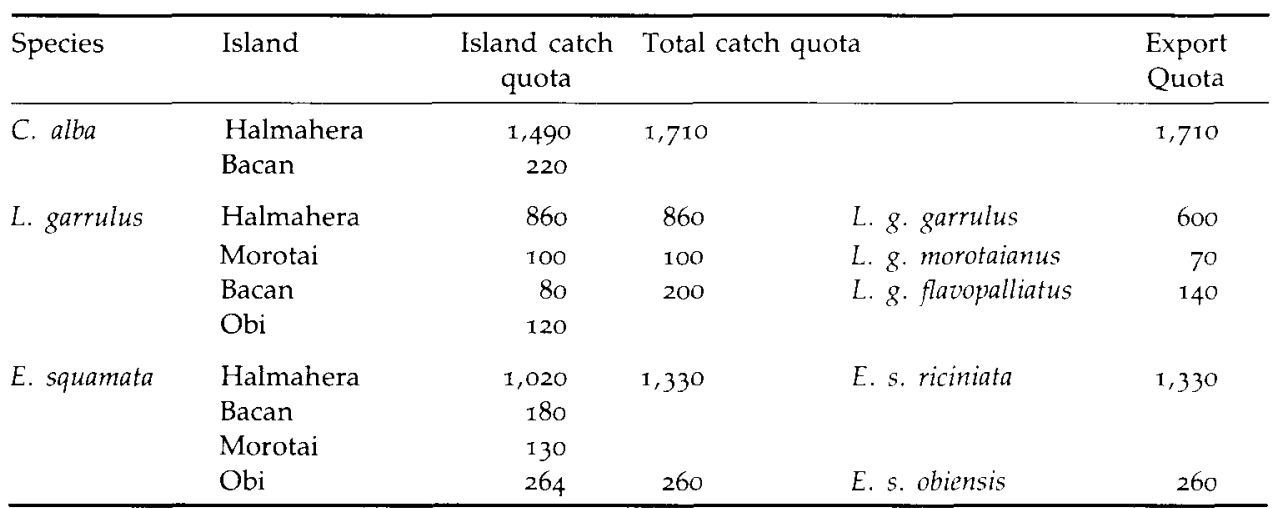


could be raised. However, this would still depend on continuing research and surveys showing that wild populations were not decreasing in number.

Export quotas suggested in Table 8 make the assumption that birds caught both legally and illegally enter the domestic market. The proportion of $C$. alba and E. squamata entering the domestic market is low, and it is assumed here that illegally caught birds would saturate this market. However, since at least $30 \%$ of L. garrulus are kept as pets within Indonesia whilst others are probably exported illegally, export quotas are set below capture quotas.

\section{Regulating and controlling trade}

There are many improvements which could be made to the regulation and control of trade in North Moluccan parrots. As a first step, an improvement in law enforcement should be a priority, because the continuation of illegal trade poses a threat to sustainability and removes revenue from the Indonesian economy.

Adjustments to the way in which the quota system is both monitored and implemented should also be considered. Major improvements in the system could be achieved if responsibility for the issuing of all permits and for the documentation of trade was allocated to one office in the Department of Forestry, Ambon.

\section{Parrot concessions}

One approach that might be beneficial to trappers, traders and those responsible for monitoring trade would be a provision of incentives not to overexploit parrots. This could perhaps be achieved through the introduction of trapping concessions which would have long-term leases, but subject to veto if infringements of quotas were proved. This might best be achieved if small islands such as Obi and Bacan were treated as single concession areas, whilst larger islands were divided on the basis of existing provincial boundaries. Concessions would be awarded to individual suppliers based in Ambon and Ternate, or to consortia of suppliers, who would then apply for or provide catch permits to local suppliers and trappers.

If practical, each concession area might be subdivided (based perhaps on topographical features) and the capture of parrots allowed in only one subdivision each year. Rotation of active subconcessions would then hopefully promote some degree of recovery if over-exploitation was occurring. The way in which such a system would affect trappers at the village level would need thorough investigation, and some form of incentive to adhere to trapping only within an active sub-concession would have to be developed. Alternatively, subconcessions could always be active, but the species targeted for capture would change each year.

Designing and implementing such a system would require considerable investment: seminars with local officials and major educational campaigns would be essential prerequisites, whilst monitoring the success of the system would be needed. 


\section{Future parrot population trends}

Whilst trade is one factor affecting parrots, another major factor is habitat loss and degradation. As noted earlier, a large proportion of the North Moluccan islands currently remains forested (RePPProT 1990). Nevertheless, timber exploitation and slowly increasing human population are responsible for the degradation and conversion of forested land.

Different parrot species will respond to these changes in different ways. Eos squamata apparently favours modified habitats and is therefore predicted to survive well in the absence of excessive trapping. Lorius garrulus and Cacatua alba, on the other hand, may not be so well adapted to these environmental changes. Although information on the breeding requirements of these two species is meagre, it is apparent that both breed in the tallest forest trees. C. alba is probably dependent on the persistence of such trees for continued breeding.

Land-use data for Bacan compiled during the course of this survey (Figure 2) provides an example of what the future holds. If the $750 \mathrm{~km}^{2}$ of forested land designated as "Conversion Forest" on Bacan were all to be cleared, and the c. $150 \mathrm{~km}^{2}$ of forest designated as Production Forest were selectively logged, a negative impact on both $C$. alba and L. garrulus populations could be expected. Based on the population densities estimated for different habitats during this survey, the present $C$. alba population could be expected to fall by at least 2,200 , resulting in a new minimum population size of c. 5,000. L. garrulus populations would fall to an even greater degree, by c. 2,500 birds. It is evident that, as development of the North Molucccan islands occurs, trade levels of C. alba and L. garrulus would have to be reduced in order to maintain sustainability. It is also evident that habitat modification and destruction is likely to be as important as, if not more important than, trade in limiting population sizes of North Moluccan parrots.

Most accessible forest in the Moluccas will have been logged by the end of this decade (officials at the Department of Forestry, Ambon, verbally 1991). This includes the majority of the lowland areas which form the most important habitat for C. alba. In contrast, L. garrulus apparently prefers, or at least survives in, hilly and steep-sided terrain, and also ranges into the mountains. Hence the effects of habitat degradation through logging can be predicted to have a more serious consequence for $C$. alba than for $L$. garrulus in the long term.

\section{Acknowledgements}

This paper is the result of a collaborative project between IUCN, the Indonesian Institute of Sciences (LIPI) and the Directorate for Forest Protection and Nature Conservation (PHPA) of the Indonesian Department of Forestry. Special thanks are extended to Dr Soetikno Wiryoatmodjo, Dr Apriliani Soegiarto, Miss Moertini, Drs Sancoyo, Ibu Dewi and Ari Budiman of LIPI; Mr Abdul Bari, Pak Widodo Ramono, Ir Ari Soedarsono, Ibu Maryanti, of PHPA; and D. Ashari and Kamil Oesman of the Indonesian Ornithological Society and SEA Zoos Association. In Ambon and Ternate, staff of the Department of Forestry and PHPA were most helpful, in particular Ir Corry Hehakaja, Ir Sonny Renbauw, Yoce Watunglawar, Pak Safe, Ir Syarifuddin, Yus Rastandi, Pak Renwarin and Pak Minto. Alwin Marakarmah (LIPI), Pak Nurdin and Yanis Patinama (PHPA) assisted with data collection during field surveys. 
I would also like to thank the following people for assistance and advice provided to this project; Dr Effendy Sumardja, Drs Marcel Silvius and the staff of AWB Indonesia, Paul Jepson and Bas van Balen (BirdLife-Indonesia), Derek Holmes (Indonesian Ornithological Society), Richard Grimmett, Adrian Long and Melanie Heath (BirdLife International), Tim Inskipp, Dr Mark Collins, Claire Billington, Joel Smith, Jonathan Rhind (WCMC), Jørgen Thomsen and Steve Broad (TRAFFIC International), Tamsin Humphreys (IUCN), Dr Pat Horning (CIDA), Stu Marsden, Dr Charles Munn, Dr Peter Evans, Richard Sapulette, Mark Linsley and Jane Loudon. Information on breeding biology and behaviour was kindly provided by the following people: Antonio de Dios, Michael Reynolds, David Williams, Susan Clubb, Rosmary Low and staff at Taman Mini. Dr Stephen Buckland provided the DISTANCE programme for data analysis, whilst Dr Martin Jones provided valuable advice on its use as well as other matters.

Comments were gratefully received from the following people: Effendy Sumardja (Forestry Department, Indonesia), Widodo Ramono (PHPA, Jakarta), Dr Stephen Edwards (IUCN), Amie Bräutigam (IUCN), Paul Jepson (BirdLife-Indonesia), Dr Bill Rainey, Dr J. Nichols (U.S. Fish and Wildlife Service), Merlin Shoesmith (Assistant Deputy Minister, Natural Resources, Manitoba), Tim Inskipp (WCMC), Drs Marcel Silvius (AWB Indonesia), Gottlieb Dändliker (CITES), Dr Martin Jones (Manchester Metropolitan University), Stephen Nash (TRAFFIC South-East Asia), David Wiedenfield (TRAFFIC U.S.A.), Dr Martin Kelsey (BirdLife International), Kathy MacKinnon (WWF) and Derek Holmes (Indonesian Ornithological Society).

This project was coordinated by Amie Bräutigam and Dr Simon Stuart of the Species Survival Commission of IUCN. Permission to publish this paper (which is the English translation, slightly edited, of the Indonesian language executive summary of Lambert [1993]) was kindly granted by Amie Bräutigam.

\section{References}

Anon. (undated) Hypothetical population response of the Red-fronted Macaw (Ara rubrogenys) to harvest mortality: an exercise in simulation modelling. Unpublished manuscript. Texas A and M University, Texas.

Beissinger, S. R. and Bucher, E. H. (1992) Sustainable harvesting of parrots for conservation. Pp.73-115 in S. R. Beissinger and N. F. R. Snyder, eds. New World parrots in crisis. Washington and London: Smithsonian Institution Press.

Beissinger, S. R. and Bucher, E. H. (in press) Can parrots be conserved through sustainable harvesting? BioScience.

Bräutigam, A. and Humphreys, T. (1992) The status of North Moluccan parrots: a summary of the findings of an IUCN field assessment. Species 19: 26-28.

Callister, D. (1989) The implementation of CITES in Indonesia. Pp.53-70 in J. Barzdo, S. R. Broad, T. P. Inskipp and R. Luxmoore, eds. Problems in CITES implementation: case studies in four selected countries. Lausanne: World Wide Fund for Nature.

Collins, N. M., Sayer, J. A. and Whitmore, T. C. (1991) The conservation Atlas of tropical forests: Asia and the Pacific. London: MacMillan.

Edwards, S. R. and Thomsen, J. B. (1992) A management framework for the wild bird trade. Pp.151-165 in J. B. Thomsen, S. E. Edwards and T. A. Mulliken, eds. Perceptions, conservation and management of wild birds in trade. Cambridge, U.K.: TRAFFIC International.

Edwards, S. R. and Nash, S. V. (1992) Wild bird trade, perceptions and management in Indonesia. Pp.93-116 in J. B. Thomsen, S. E. Edwards S. E. and T. A. Mulliken, eds. Perceptions, conservation and management of wild birds in trade. Cambridge, U.K.: TRAFFIC International.

Forshaw, J. M. (1989) Parrots of the world. Third edition. Melbourne: Lansdowne Editions. 
Inskipp, T. Broad, S. and Luxmoore, R., eds. (1988) Significant trade in wildlife: a review of selected species in CITES Appendix II, volume 3: Birds. Cambridge, U.K.: International Union for Conservation of Nature and Natural Resources, and Secretariat of the Convention on International Trade in Endangered Species of Wild Fauna and Flora.

Laake, J. L., Buckland, S. T., Anderson, D. R. and Burnham, K. P. (1991) Distance sampling: abundance estimation of biological populations. Unpublished (IBM compatible) software.

Lambert, F. R. (1993) The status of and trade in North Moluccan parrots with particular emphasis on Cacatua alba, Lorius garrulus and Eos squamata. Gland, Switzerland, and Cambridge, U.K.: International Union for Conservation of Nature and Natural Resources (IUCN/SSC Trade Specialist Group).

Lendon, A. H. (1946) Memories of the Moluccas. Avicult. Mag. 52: 206-213.

LIPI (1991) Survei populasi buring di bakal kawasan transmigrasi Kabupaten Merauke, Irian Jaya. Bogor, Indonesia: Indonesian Institute for Sciences (LIPI), unpublished.

Low, R. (1988) Parrots, their care and breeding. Second edition. London: Blandford.

Mace, G. M. and Lande, R. (1991) Assessing extinction threats: towards a re-evaluation of IUCN threatened species categories. Conserv. Biol. 5: 148-157.

Milton, G. R. and Marhadi, A. (1987) An investigation of parrots and their trade on Pulau Bacan (north Moluccas) and Pulau Warmar, Aru Islands. Bogor, Indonesia: WWF/IUCN Conservation for Development Programme in Indonesia.

Nash, S. V. (1990) Psittacine trade of Irian Jaya, Indonesia. Jayapura, Indonesia: World Wide Fund for Nature.

Nash, S. (1992) Parrot trade records for Irian Jaya, Indonesia, 1985-1990. TRAFFIC Bull. 13: $1-2$.

Noerdjito, M. (1986) Keadaan populasi Cacatua galerita aruensis Mathews di kepulauan Aru dan malaslah kelestariannya. Rimba Indonesia 20: 15-26.

RePPProT (1990) National overview of the Regional Physical Planning Programme for Transmigration. Chatham, U.K.: Overseas Development Natural Resources Institute.

Smiet, F. (1985) Notes on the field status and trade of Moluccan parrots. Biol. Conserv. 34: 181-194.

FRANK R. LAMBERT

IUCN Trade Specialist Group, 219 Huntingdon Road, Cambridge CB3 ODL, U.K. 